\title{
Microscopic species make the diversity: a checklist of marine flora and fauna around the Island of Sylt in the North Sea
}

\author{
Werner Armonies* (1), Harald Asmus (1), Christian Buschbaum (1), Dagmar Lackschewitz, Karsten Reise (i) \\ and Johannes Rick(i)
}

\begin{abstract}
Based on the past 150 years of research and ongoing time-series observations we give a comprehensive overview of marine species composition around the island of Sylt in the eastern North Sea. A total of 2758 species is listed according to the categories microplankton (591 species), zooplankton (137), nekton (118), benthic microflora (158), benthic macroflora (125), benthic micro-and meiofauna (1204), benthic macrofauna (509), birds and mammals (91), and neobiota (39). Plants account for a third of the species, most (85\%) of them are microscopic Chromista. Among animals, $60 \%$ of the species are micro- and meiofauna though this faunal component is still insufficiently known. These figures are similar to records from the southern North Sea and therefore may by typical for temperate climate sedimentary coastal areas. A comparison with the total of marine species suggests that the small benthic fauna may be severely understudied over most of the world. Analysis of global change depends on sound baseline data and species inventories like this can assist in the detection of biodiversity changes. They emphasise rare species and the full range of local habitats while time-series measurements usually rely on a few selected habitats and biotic components to generate a very general picture of the state of an ecosystem.
\end{abstract}

Keywords: Marine biodiversity, Species inventory, Long-term ecological research

\section{Background}

Biological research has a long tradition in the North Sea and especially around the German island of Sylt in the north-Frisian Wadden Sea. Here, Möbius [1] began with studies on the associated species community of oyster beds in the middle of the nineteenth century. In 1924 the Biologische Anstalt Helgoland founded an oyster laboratory in the village of List on Sylt, which has developed over the decades to the current Wadden Sea Station Sylt, belonging to the Alfred Wegener Institute, Helmholtz Centre for Polar and Marine Research (German: Wattenmeerstation Sylt, Alfred-Wegener-Institut Helmholtz-Zentrum für Polar- und Meeresforschung). In the first half of the previous century, benthic research

\footnotetext{
*Correspondence: Werner.Armonies@awi.de
}

Alfred-Wegener-Institut Helmholtz-Zentrum für Polar- und

Meeresforschung, Wattenmeerstation Sylt, Hafenstr. 43, 25992 List, Germany was continued by Hagmeier and Kändler [2]. Additionally, Nienburg [3] described the vegetation and Wohlenberg [4] the tidal flat benthos of Königshafen, the bay adjacent to the Wadden Sea Station at the northern tip of the island of Sylt, where most field research has been conducted and student courses studied and still investigate the biology of coastal organisms. Künne was the first to devote a study to the regional plankton [5].

Several studies in the coastal ecosystem have repeated surveys from early in the twentieth century $50-80$ years later to reveal temporal change [e.g. 6, 7]. During recent decades, regular observations were initiated which are still carried on. All these studies together with numerous contributions by guest scientists of the Wadden Sea Station Sylt provided the sources for the lists of species compiled for the sea around the island of Sylt. Although there are still gaps-not all taxa have yet been studied or listed-this is an exceptionally comprehensive

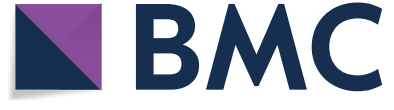

(c) The Author(s) 2018. This article is distributed under the terms of the Creative Commons Attribution 4.0 International License (http://creativecommons.org/licenses/by/4.0/), which permits unrestricted use, distribution, and reproduction in any medium, provided you give appropriate credit to the original author(s) and the source, provide a link to the Creative Commons license, and indicate if changes were made. 
compilation of species found in a coastal sea. More than 150 years of research have contributed to this treasure of marine biological science. Facing enhanced global warming and biological globalization as well as local human pressure, this regional assessment of species richness will be of outstanding value for understanding and then hopefully managing the rapid change in coastal biodiversity.

\section{Methods}

The island of Sylt lies in the northern Wadden Sea in the eastern part of the North Sea. This is a shallow coastal region with a chain of barrier islands. The distance from the exposed sandy barrier to the sheltered mainland marshes is about $10 \mathrm{~km}$. Mean tidal range is about $2 \mathrm{~m}$. Behind barrier islands, about half of the sea floor is exposed by diurnal tides. The sea floor is sedimentary, natural hard substrata are limited to epibenthic mussel and oyster beds. Sand flats prevail over mud flats. These are dissected by tidal channels with depths down to $40 \mathrm{~m}$. Of the total water volume, about half is exchanged each tide with the coastal North Sea. From the exposed sandy beaches of barrier islands and shoals of ebb deltas, depth gradually slopes down to $30 \mathrm{~m}$ over a distance of $80 \mathrm{~km}$ offshore (Fig. 1). A detailed description of the tidal area around the island of Sylt including its biota and abiotic conditions is provided by Reise [8] and Gätje and Reise [9].

For species names we used the World Register of Marine Species (http://www.marinespecies.org) as a reference [10], only few species were not yet included in WoRMS. The latest update of the species names in our lists was in March 2018; changes of species names at a later date can be examined by following the link to WoRMS given with each species. Each taxon list was compiled and checked by an expert in the respective group of organisms to ensure data quality.

\section{Results}

(1) Microplankton-Additional file 1: Table S1

The microplankton check list results from a longterm time series initiated by Gerhard Drebes and Malte Elbrächter who have sampled and analysed net plankton from Sylt-Rømø Bight from the early seventies. In 1987 the protocol was standardized and is now known as the semi-quantitative Sylt Roads time series [47] consisting of weekly samples (20 and $80 \mu \mathrm{m}$ nets) from a fixed station (Fig. $1 ; 55.03^{\circ} \mathrm{N}, 008.46^{\circ} \mathrm{E}$ ). Evaluation of the live material starts $<1 \mathrm{~h}$ after sample collection

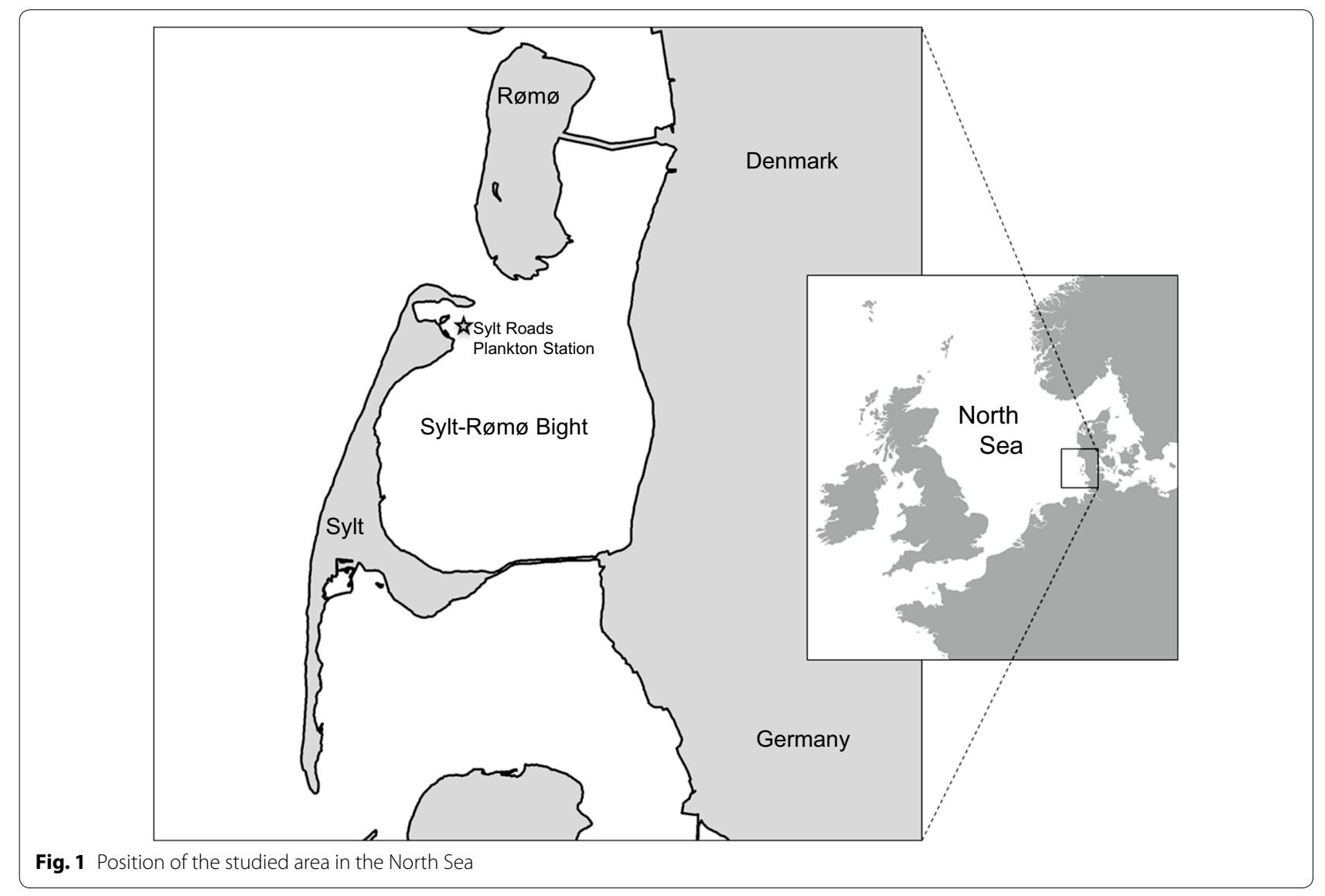


and includes an inspection with a dissection microscope followed by an intense analysis (90 $\mathrm{min}$ ) with a Leitz Aristoplan microscope using seawater immersion lenses 25 and $50 \times$ with final magnification of $250 \times$ and $500 \times$.

Major data sources: Rick et al. [48], Elbrächter [11] and Hoppenrath et al. [12]

\section{(2) Zooplankton-Additional file 1: Table S2}

Starting from a basic study by Hickel [13], Peter Martens initiated a long-term time series on Zooplankton in Sylt-Rømø bight in 1975 which is still continued. The zooplankton species list is based on these data, completed with data on bivalve larvae [14] and gelatinous zooplankton [15].

Major data sources: Martens $[49,50]$

\section{(3) Nekton-Additional file 1: Table S3}

The Nekton checklist results from the records of fish stocks in Sylt Rømø Bight that are part of Sylt Roads long-term ecological research since 2006. Monthly fish stock assessments cover seven stations along the main branches of the tidal inlet and additional quarterly hauls from the ebb delta of the main tidal channel and from the inner bay. Quantitative data on the fish records are available at PANGAEA. Besides these current state data, the list also contains historical data for fish that are absent in our days, based on an unpublished previous list compiled by Harald Asmus, Patrick Polte, and Christian Buschbaum in 2002.

(4) Benthic microflora-Additional file 1: Table S4

The microphytobenthos checklist is a taxonomically updated version of earlier unpublished compilations by Asmus on diatoms, and Hoppenrath on dinoflagellates and Euglenophyceae.

Major data sources: Drebes [16], Asmus [17], Asmus and Bauernfeind [18] and Hoppenrath [19-21]

(5) Benthic macroflora-Additional file 1: Table S5

A high number of macroalgal species occurring around the island of Sylt have already been described in Kornmann and Sahling [22]. Twenty years later, Schories et al. [23] gave a first comprehensive overview on macroalgae species in the area. The present list of species is based on this compilation, expanded by published original papers and unpublished Ms. and Ph.D. theses dealing with macroalgae. In addition, the herbal material available at Wadden Sea Station Sylt was evaluated.
Major data sources: Kornmann and Sahling [22] and Schories et al. [23]

(6) Benthic Micro- and Meiofauna-Additional file 1: Table S6

In 2002 and 2003, Gerlach compiled a checklist of micro- and meiofauna in the Wadden Sea of SchleswigHolstein and Denmark [24] including detailed references for each species. Since there were no major studies on local meiofauna in the meantime, only some 20 species have been added which means minor change in a list of some 1200 species. However, advanced methods in taxonomy led to major changes in systematics. As a result, some 160 of the species have been re-named since 2004 . Additional file 1: Table S6 is an update of Gerlach [24] including these changes.

Major data sources: Gerlach [24] and Armonies [51]

(7) Benthic Macrofauna-Additional file 1: Table S7

This species inventory is based on an internal list of macrobenthic species in the Northern Wadden Sea compiled by Christian Buschbaum and Karsten Reise in the year 2002, covering the published data as well as unpublished Ms. and Ph.D. theses until the year 2000. This list was expanded to include the North Sea off Sylt down to some $30 \mathrm{~m}$ depth and updated with respect to current species names. However, most data come from smallsized sediment samples (box or Van Veen cores); therefore, large sized benthos (megafauna) is not adequately represented in this listing.

Major data sources: Buschbaum and Reise (unpublished) and Armonies and Reise [52] for the Wadden Sea; Armonies and Buschbaum [53] and Armonies et al. [54, 55] for the North Sea off Sylt

(8) Birds and mammals-Additional file 1: Table S8

A first species inventory for birds and mammals was compiled by Birgit Hussel in 2002 and included terrestrial species recorded at the island of Sylt. Recent updates of this list also consider the reference material in Berndt [25] and Koop and Berndt [26, 27] and recent new findings in the online portal www.ornitho.de. In addition, the list was updated using monitoring data along the coast of the island of Sylt provided by Landesamt für Küstenschutz und Nationalpark des Landes Schleswig- Holstein (birds) and quantitative data provided by Institut für Terrestrische und Aquatische Wildtierforschung, Stiftung der Tierärztlichen Hochschule Hannover in Büsum and the Fiskeri- og Sjøfartsmuseet, Esbjerg (mammals) and from literature sources of master and doctoral theses. 
Major data sources: Pfeifer [28].

(9) Neobiota-Additional file 1: Table S9

Neobiota includes non-indigenous species (NIS) and cryptogenic species (for which we have no firm proof that they are introduced). Our list is based on data from 'Rapid Assessment Surveys (RAS)' for monitoring alien species in German coastal waters, conducted annually since 2009 and funded by state and federal authorities. In addition, investigations performed during Ms. and Ph.D. theses at Wadden Sea Station Sylt were evaluated. This revealed several species new for Sylt and ten species new for the entire German coast.

Major data sources: Buschbaum et al. [29], Lackschewitz et al. [30], Lackschewitz and Buschbaum [31], Nehring and Leuchs [32] and Reise et al. [33].

\section{Discussion}

Combining all species lists, we are now aware of 2758 marine species in the Sylt area (Table 1; corrected for double occurrences of species as may result, for instance, from listing adults as macrozoobenthos and their larvae as zooplankton). A third of the species are plants, mostly (85\%) microscopic sized Chromista. Macrofauna (adults retained on a $1 \mathrm{~mm}$ sieve) account for $25 \%$ of species richness and meiofauna (adults pass a $1 \mathrm{~mm}$ sieve but are retained on $63 \mu \mathrm{m}$ meshes) for $38 \%$ while the contribution of microfauna (adults pass a $63 \mu \mathrm{m}$ sieve) is small (2.5\%). Thus, microscopic flora and fauna account for two-thirds of marine species diversity.

The Sylt partitioning of marine species richness over kingdoms and phyla is quite similar to the coastline of Belgium [34]. This is a similar sized sedimentary shallow coast in the southern North Sea some $500 \mathrm{~km}$ (aerial distance) southwest of Sylt. In many taxa the numbers of species recorded in both areas are almost identical (Table 2) although we expected effects of the less complex geomorphology along the Belgian coastline (no barrier islands and therefore less sheltered habitats) which might reduce species richness while the neighbourhood of the Belgian coastline to the open eastern Atlantic might increase species richness. Major differences between the southern and eastern North Sea only occur in sessile taxa, in particular in bryozoans which are only rudimentary known in the Sylt area because only some natural biogenic hard substrata have been studied, so far. Differences in single meiofaunal taxa are also explained by varying study intensity: Xenacoelomorpha, Gnathostomulida, or Acari have not yet been studied along the Belgian coastline, accordingly the number of recorded species is zero. On the other hand, just a single major study each was devoted
Table 1 Taxonomic species composition of flora and fauna around the Island of Sylt in the North Sea

\begin{tabular}{|c|c|c|}
\hline & No of species & Table \\
\hline \multicolumn{3}{|l|}{ Bacteria } \\
\hline Cyanophyceae & 1 & 1.11 \\
\hline \multicolumn{3}{|l|}{ Protozoa } \\
\hline Amoebozoa & 3 & 1.01 \\
\hline Choanozoa & 9 & 1.08 \\
\hline Euglenozoa & 49 & $1.13,4.03$ \\
\hline Incertae sedis & 7 & 1.16 \\
\hline \multicolumn{3}{|l|}{ Chromista } \\
\hline \multicolumn{3}{|l|}{ Hacrobia } \\
\hline Cryptophyta & 7 & 1.10 \\
\hline Haptophyta & 19 & 1.03 \\
\hline Heliozoa & 1 & 1.14 \\
\hline \multicolumn{3}{|l|}{ Alveolata } \\
\hline Ciliophora & 123 & 6.02 \\
\hline Dinophyceae & 263 & $1.02,4.02$ \\
\hline \multicolumn{3}{|l|}{ Heterokonta } \\
\hline Bigyra Bicosoecia & 2 & 1.06 \\
\hline Bacillariophyceae & 278 & $1.01,4.01$ \\
\hline Phaeophyceae & 39 & 5.02 \\
\hline Dictyochophyceae & 7 & 1.12 \\
\hline Raphidophyceae & 7 & 1.17 \\
\hline Xanthophyceae & 1 & 1.21 \\
\hline Oomycota & 10 & $1.15,1.09$ \\
\hline \multicolumn{3}{|l|}{ Rhizaria } \\
\hline Cercozoa & 6 & 1.18 \\
\hline Foraminifera & 7 & 6.01 \\
\hline Radiozoa & 2 & $1.04,1.20$ \\
\hline \multicolumn{3}{|l|}{ Plantae } \\
\hline Chlorophyta & 62 & $1.07,5.01$ \\
\hline Fucophyceae & 39 & 5.02 \\
\hline Rhodophyta & 38 & $5.03,1.19$ \\
\hline Tracheophyta & 8 & 5.04 \\
\hline \multicolumn{3}{|l|}{ Animalia } \\
\hline Porifera & 3 & 7.01 \\
\hline Cnidaria & 47 & $2.01,7.02,6.03$ \\
\hline Ctenophora & 5 & 2.02 \\
\hline Echinodermata & 12 & $2.08,7.18$ \\
\hline Xenacoelomorpha & 65 & 6.04 \\
\hline Platyhelminthes & 337 & $2.10,6.05$ \\
\hline Nemertea & 8 & $7.04,6.07$ \\
\hline Gastrotricha & 60 & 6.09 \\
\hline Gnathostomulida & 10 & 6.06 \\
\hline Rotifera & 30 & 6.08 \\
\hline Nematoda & 321 & 6.10 \\
\hline Kinorhyncha & 2 & 6.11 \\
\hline \multicolumn{3}{|l|}{ Mollusca } \\
\hline Bivalvia & 65 & $2.04,7.07$ \\
\hline Polyplacophora & 1 & $2.03,7.05$ \\
\hline Gastropoda & 38 & 7.06 \\
\hline
\end{tabular}


Table 1 (continued)

\begin{tabular}{|c|c|c|}
\hline & No of species & Table \\
\hline \multicolumn{3}{|l|}{ Annelida } \\
\hline Polychaeta & 152 & $2.05,6.12,7.08$ \\
\hline Oligochaeta & 46 & $7.09,6.13$ \\
\hline \multicolumn{3}{|l|}{ Arthropoda } \\
\hline \multicolumn{3}{|l|}{ Chelicerata } \\
\hline Acari & 28 & 6.15 \\
\hline Pycnogonida & 6 & 7.17 \\
\hline \multicolumn{3}{|l|}{ Crustacea } \\
\hline Ostracoda & 22 & 6.16 \\
\hline Cirripedia & 6 & 7.11 \\
\hline Copepoda & 146 & $6.17,2.07$ \\
\hline Phyllopoda & 3 & 2.07 \\
\hline Amphipoda & 88 & $7.10,3.01$ \\
\hline Cumacea & 17 & 7.12 \\
\hline Decapoda & 26 & $7.13,3.01$ \\
\hline Isopoda & 8 & 7.14 \\
\hline Mysida & 12 & $7.15,3.1$ \\
\hline Tanaidacea & 1 & 7.16 \\
\hline Tardigrada & 3 & 6.14 \\
\hline Insecta & 3 & 7.21 \\
\hline Bryozoa & 14 & $2.11,7.03$ \\
\hline Phoronida & 2 & 7.22 \\
\hline Sipuncula & 1 & 7.23 \\
\hline Chaetognatha & 2 & 2.06 \\
\hline Hemichordata & 1 & 7.19 \\
\hline \multicolumn{3}{|l|}{ Chordata } \\
\hline Tunicata & 10 & $2.9,7.20$ \\
\hline Pisces & 78 & $3.2,7.24$ \\
\hline Aves & 88 & 8.1 \\
\hline Mammalia & 3 & 8.2 \\
\hline Total species & 2758 & \\
\hline
\end{tabular}

Table numbers refer to Additional file 1: Tables S1-S9

to Nematoda, Copepoda and Ostracoda in the Sylt area but several or many along the Belgian coast, hence more species are recorded from Belgium. Obviously, there are still major gaps of knowledge on meiofauna at both sites. Nevertheless, the similarity or records indicates that the relative contributions of taxa may be typical for the North Sea.

Phytoplankton is not included in the Belgian data but we found a comparable phytoplankton checklist for the sea off Roscoff (France) close to the southern border of the North Sea [35]. They report on 211 phytoplankton species (including 152 species of diatoms and 42 of dinoflagellates) which is only a third of the Sylt number. Again, this may be due to lower sampling intensity (10 years with 200 samples near Roscoff versus 30 years with >1400 samples near Sylt) and the local availability of taxonomic expertise. Most (85\%) of the Roscoff species also occur near Sylt indicating the phytoplankton species spectrum may be rather similar all over the North Sea. The remaining $15 \%$ of phytoplankton species found near Roscoff but not near Sylt are predominantly Lusitanian or Atlantic species as expected from the geographical position of Roscoff.

On a world-wide scale the number of species recorded from Sylt (2758) roughly equals $1 \%$ of the number of marine species described (some 240,000) [10], and $8 \%$ of the species recorded from European waters (some 33,500) [36]. Again, there are strong variations over taxonomic units (Additional file 1: Table S12). Reasons for low representation of taxa in the eastern North Sea include a lack of local studies as in Bacteria and Fungi, habitat effects such as the local lack of hard substrata (e.g., Porifera, Bryozoa, macroalgae, with effects on the associated fauna), and geographical restrictions in some taxa. On the other hand, in the North Sea some faunal taxa include exceptionally high percentages of the worldwide known species. This may be due to wide geographic ranges of the species brought about by wide physiological tolerance and/or high mobility of species as in birds. For other taxa such as Xenacoelomorpha, Platyhelminthes, Gastrotricha, Gnathostomulida, and Rotifera the exceptional high study intensity in the North Sea is a likely cause. But since there are no reasons why meiofaunal species richness should by higher in the North Sea than along other coastlines of the world, these high percentages indicate that small fauna is severely understudied over most of the world. As a consequence, without adequate registration of the small flora and fauna marine diversity is likely to be strongly underestimated.

\section{Limitations of the compiled species lists}

Despite the wealth of species recorded from Sylt our compilations are not complete but species richness of major taxa is biased by varying study intensity. This explains the high species numbers for many meiofaunal taxa that were intensively studied in the 1970s [37] as well as the low species number for bacteria and fungi that have not been studied at all in the sea surrounding the island of Sylt, up to now. In addition, habitats have not been equally studied. As an example, though a high number of meiofaunal species has been listed, most of them were recorded from inter- or supratidal habitats while nearly nothing is known about their counterparts living in the subtidal. Since these organisms may dominate benthic species richness from the shallows [38] to the deep sea [39] the lack of studies in the subtidal part of our study area results in an underestimate of micro- and meiofaunal species richness. 
Table 2 Species richness along the coastlines of Belgium (southern North Sea) and the island of Sylt (eastern North Sea)

\begin{tabular}{|c|c|c|}
\hline & Sylt & Belgium \\
\hline Protozoa & 68 & na \\
\hline Chromista & 772 & na \\
\hline Plantae & 143 & 131 \\
\hline Animalia, total & 1772 & 2056 \\
\hline Macrofauna, predominantly sessile & 23 & 217 \\
\hline Porifera & 3 & 34 \\
\hline Cirripedia & 6 & 27 \\
\hline Bryozoa & 14 & 156 \\
\hline Macrofauna, predominantly mobile & 678 & 886 \\
\hline Polychaeta ${ }^{a}$ & 152 & 152 \\
\hline Mollusca & 104 & 129 \\
\hline Pisces & 78 & 127 \\
\hline Aves & 88 & 75 \\
\hline Amphipoda & 88 & 71 \\
\hline Decapoda & 26 & 72 \\
\hline Cnidaria & 47 & 55 \\
\hline Isopoda & 8 & 33 \\
\hline Echinodermata & 12 & 27 \\
\hline Cumacea & 17 & 13 \\
\hline Mysida & 12 & 18 \\
\hline Tunicata & 10 & 11 \\
\hline Nemertea $^{a}$ & 8 & 12 \\
\hline other macrofaunal taxa & 28 & 93 \\
\hline Meiofauna & 1071 & 953 \\
\hline Nematoda & 322 & 473 \\
\hline Platyhelminthes ${ }^{b}$ & 337 & 161 \\
\hline Copepoda & 146 & 194 \\
\hline Ostracoda & 22 & 56 \\
\hline Gastrotricha & 60 & 36 \\
\hline Xenacoelomorpha & 65 & 0 \\
\hline Oligochaeta $^{\mathrm{b}}$ & 46 & 11 \\
\hline Rotifera & 30 & 20 \\
\hline Acari & 28 & 0 \\
\hline Gnathostomulida & 10 & 0 \\
\hline Kinorhyncha & 2 & 2 \\
\hline Tardigrada & 3 & 0 \\
\hline
\end{tabular}

na no data available

a Includes a few meiofaunal species

b Includes a few macrofaunal species

Besides these shortcomings in habitat cover, coastal systems are often highly dynamic and can be subject to strong diversity changes. The Sylt Roads phytoplankton series gives examples for temporal variability in both species richness and community composition. On an annual basis, the mean number of phytoplankton species per (weekly) sample did not significantly change during the past 25 years and variability between years seems to be moderate (Fig. 2 top). However, based on seasons variability between years is more conspicuous, in particular in summer and autumn, while a long-term decrease in the mean number of phytoplankton species becomes evident for the spring season. Following strong ice winters (1996, 2010) this number is especially low for the subsequent spring season. On short temporal scales, variability in species richness is also highest in summer and autumn, as indicated by the error bars (Fig. 2). With respect to community composition the Sylt Roads phytoplankton changed between 1987 and 2013 in parallel to rising sea surface temperature and decreasing eutrophication, with smallest change in the high biomass species and strongest change in the less frequent occurring species [40].

Finally, man-made translocations of species (intentional or accidentally) contribute to changes in species richness. Currently, the number of non-indigenous species still seems low (39 out of 2758 equivalent to $1.4 \%$ ) but some of the introduced species already had fundamental effects on the communities [41]. Examples are American razor clams Ensis leei which became a dominant bivalve in terms of abundance and biomass in the subtidal zone of the Wadden Sea [42], Pacific oysters Magallana (Crassostrea) gigas which turned the former mussel (Mytilus edulis) beds into combined oyster/mussel beds [43, 44], or the Japanese seaweed Sargassum muticum which forms extensive beds in the shallow subtidal zone and nowadays functionally replaces former native seagrass (Zostera marina) beds that almost went extinct in the 1930s due to a parasitic slime mould [45] and failed to recover to their original extension, up to now. Most of the non-indigenous species recorded so far are either planktonic or large benthic species. Presumably, this is an artefact brought about by study intensity which is highest for planktonic and macrobenthic communities while for small-sized micro- and meiofauna low sampling intensity meets insufficient knowledge of the species thus preventing non-indigenous species to be recognized. Our species inventory intends to reduce this bias.

\section{Benefits of species checklists}

Local species checklists may be a useful tool to assist students in species identification. They provide regional baseline data to detect natural diversity developments and the impact of local anthropogenic pressures, hence provide a data source for management measures and decisions [46]. Nevertheless, comprehensive species inventories like ours are extremely scarce, on a world-wide scale. The reasons for this rarity certainly include the large effort needed to compile the data. More important, however, may be the need for taxonomic experts for the various taxa. Therefore a checklist usually can only be compiled (or updated) by treating taxa one-by-one, as an expert is available, and it may take decades until all taxa are included. 

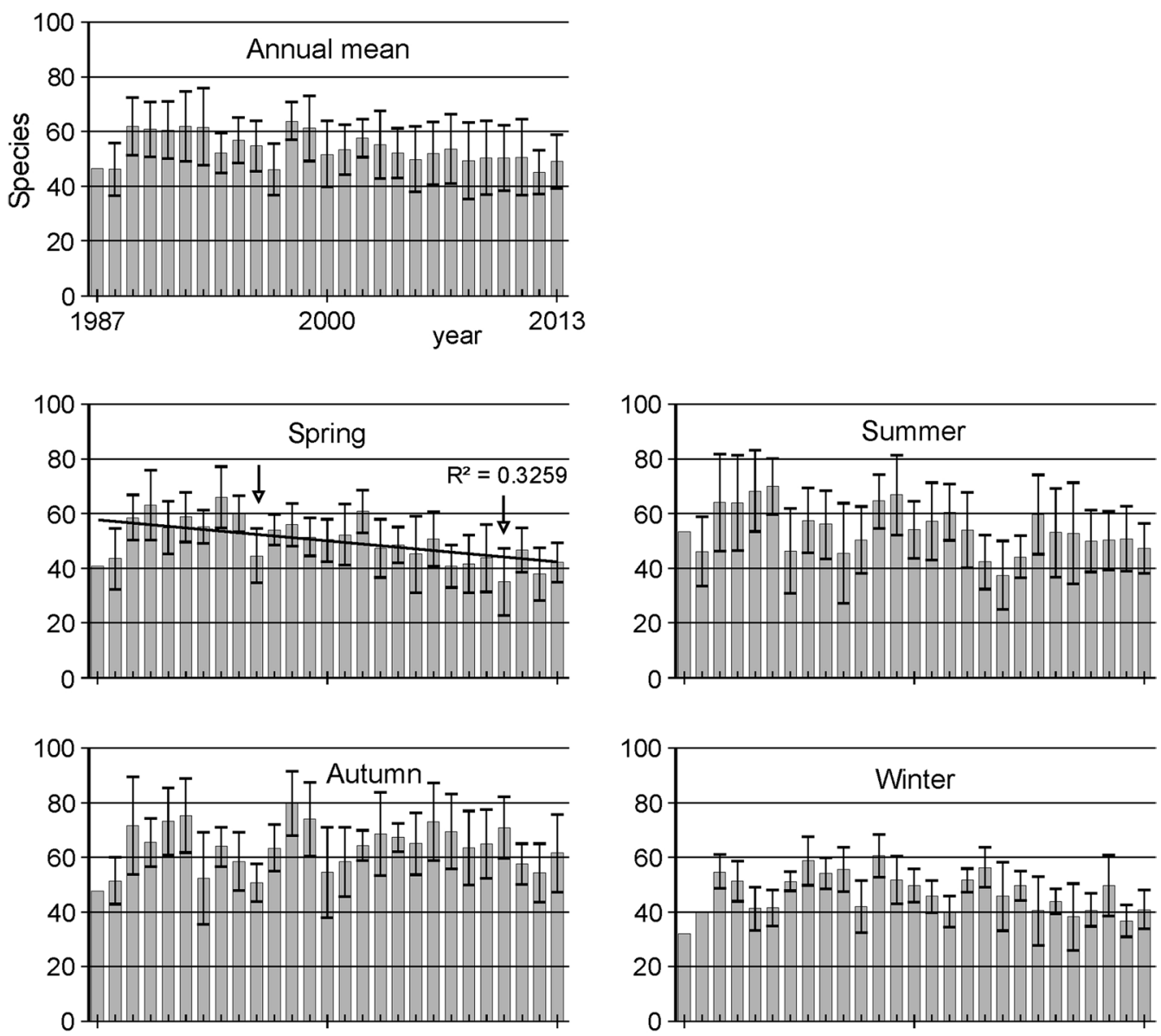

Fig. 2 Phytoplankton species richness in the Sylt Roads time series. Mean number of species per weekly sample \pm standard error for entire years (annual mean) and single seasons. The $\mathrm{R}^{2}$ in spring refers to a linear regression and the arrows indicate low values after strong ice winters

Despite their rarity, comprehensive checklists may fundamentally contribute to analysis of global change. Since long-term ecological research and time-series measurements are usually cost-limited they need to concentrate on a few selected habitats and biotic components. This may yield excellent data on some abundant species and may be used as a proxy for the general state of an ecosystem but fails to detect change in rare species and all the components not included in the time-series. Updated species inventories are highly useful to fill that gap.

\section{Additional files}

Additional file 1. Marine flora and fauna around the Island of Sylt in the North Sea. Table S1. Microplankton; Table S2. Zooplankton; Table S3. Nekton; Table S4. Benthic microflora; Table S5. Benthic macroflora; Table S6. Benthic micro- and meiofauna; Table S7. Benthic macrofauna; Table S8. Birds and mammals; Table S9. Neobiota; Table S10. Number of species per table; Table S11. Taxonomic species composition around Sylt; Table S12. Comparison of species composition around Sylt with European waters and the world oceans.
Authors' contributions

All authors contributed to both the text and Additional file 1. All authors read and approved the final manuscript.

\section{Acknowledgements}

None.

\section{Competing interests}

The authors declare that they have no competing interests.

\section{Availability of data and materials}

The datasets generated during the current study are available in Additional file 1. Major datasets used during the current study are listed in 'Data sets'.

\section{Ethics approval and consent to participate}

Not applicable. This article does not contain any studies with animals performed by any of the authors.

\section{Funding}

This study was completely funded by our home institute-no third-party funding.

\section{Publisher's Note}

Springer Nature remains neutral with regard to jurisdictional claims in published maps and institutional affiliations. 
Received: 7 December 2017 Accepted: 20 June 2018

Published online: 26 June 2018

\section{References}

1. Möbius K. Die Auster und die Austernwirthschaft. Wiegandt, Hempel \& Parey; 1877

2. Hagmeier A, Kändler R. Neue Untersuchungen im nordfriesischen Wattenmeer und auf den fiskalischen Austernbänken. Wiss Meeresunters (Helgoland). 1927;16:1-90.

3. Nienburg W. Zur Ökologie der Flora des Wattenmeeres. I. Der Königshafen bei List auf Sylt. Wiss Meeresunters (Kiel). 1927:20:146-96.

4. Wohlenberg E. Die Wattenmeer-Lebensgemeinschaften im Königshafen von Sylt. Helgol wiss Meeresunters. 1937;1:1-92.

5. Künne C. Untersuchungen über das Großplankton in der Deutschen Bucht und im Nordsylter Wattenmeer. Helgol wiss Meeresunters. 1952:4:1-54.

6. Riesen W, Reise K. Macrobenthos of the subtidal Wadden Sea: revisited after 55 years. Helgol Meeresunters. 1982;35:409-23.

7. Reise K, Herre E, Sturm M. Historical changes in the benthos of the Wadden Sea around the island of Sylt in the North Sea. Helgol Meeresunters. 1989;43:417-33

8. Reise K. Tidal flat ecology. Berlin: Springer; 1985.

9. Gätje C, Reise K. Ökosystem Wattenmeer. Austausch-, Transport- und Stoffumwandlungsprozesse. Berlin: Springer; 1998.

10. WoRMS Editorial Board. World Register of Marine Species. Vlaams Instituut voor de Zee (VLIZ). 2018. http://www.marinespecies.org. Accessed 8 March 2018.

11. Elbrächter M. Exotic flagellates of coastal North Sea waters. Helgol Meeresunters. 1999:52:235-42.

12. Hoppenrath M, Elbrächter M, Drebes G. Marine Phytoplankton—selected mircoplankton species from the North Sea around Helgoland and Sylt. Stuttgart: Schweizerbart; 2009.

13. Hickel W. The mesozooplankton in the Wadden Sea of Sylt (North Sea) Helgol wiss Meeresunters. 1975;27:254-62.

14. Strasser M, Guenther CP. Larval supply of predator and prey: temporal mismatch between crabs and bivalves after a severe winter in the Wadden Sea. J Sea Res. 2001;46:57-67.

15. Kopacz U. Gelatinöses Zooplankton und Chaetognatha im Sylter Seegebiet. Göttingen: Cuvillier; 1996

16. Drebes G. Marines phytoplankton. Stuttgart: Thieme; 1974.

17. Asmus R. Benthische und pelagische Primärproduktion und Nährsalzbilanz. No: Ber Inst Meeresk Kiel; 1984. p. 131

18. Asmus R, Bauerfeind E. The microphytobenthos of Königshafen—spatial and seasonal distribution on a sandy tidal flat. Helgol Meeresunters. 1994:48:257-76

19. Hoppenrath M. Morphology and taxonomy of the marine sand-dwelling genus Thecadinium (Dinophyceae), with the description of two new species from the North German Wadden Sea. Phycologia. 2000;39:96-108.

20. Hoppenrath M. Morphology and taxonomy of six marine sand-dwelling Amphidiniopsis species (Dinophyceae, Peridiniales), four of them new, from the German Bight, North Sea. Phycologia. 2000;39:482-97.

21. Hoppenrath M. Morphology and taxonomy of Sinophysis (Dinophyceae, Dinophysiales) including two new marine sand-dwelling species from the North German Wadden Sea. Europ J Phycol. 2000;35:153-62.

22. Kornmann P, Sahling PH. Meeresalgen von Helgoland, benthische Grün-, Braun- und Rotalgen. Helgol wiss Meeresunters. 1977;29:1-289.

23. Schories D, Albrecht A, Lotze H. Historical changes and inventory of macroalgae from Königshafen Bay in the northern Wadden Sea. Helgol Meeresunters. 1997:51:321-41.

24. Gerlach SA. Die Biodiversität in der deutschen Nord- und Ostsee Band 2: Checkliste der Mikro- und Meiofauna im schleswig-holsteinischen und dänischen Wattenmeer. Bericht BfG-1397, Bundesanstalt für Gewässerkunde, Koblenz; 2004.

25. Berndt RK. Geschichte der Feldornithologie Schleswig Holsteins und Hamburgs. Vogelwelt Schleswig-Holsteins, Band 8. Wachholtz Murmann, Kiel; 2015.

26. Koop B, Berndt RK. Brutvogelatlas. Vogelwelt Schleswig-Holsteins, Band 5. Wachholtz Murmann, Kiel; 2003.
27. Koop B, Berndt RK. Zweiter Brutvogelatlas. Vogelwelt Schleswig-Holsteins, Band 7. Wachholtz Murmann, Kiel; 2014.

28. Pfeifer G. Die Vögel der Insel Sylt. Husum: Husum Druck- und Verlagsgesellschaft; 2003.

29. Buschbaum C, Lackschewitz D, Reise K. Nonnative macrobenthos in the Wadden Sea ecosystem. Ocean Coast Manag. 2012;68:89-101.

30. Lackschewitz D, Reise K, Buschbaum C, Karez R (2015) Neobiota in deutschen Küstengewässern. Schriftenreihe LLUR SH-Gewässer, D25.

31. Lackschewitz D, Buschbaum C (2018) Status und Verbreitung der Gebietsfremden Arten (Neobiota) in deutschen Küstengewässern von Nordund Ostsee. BfN Report (in prep.).

32. Nehring S, Leuchs H. Neozoa (Makrobenthos) an der deutschen Nordseeküste. Koblenz: Eine Übersicht. Bundesanstalt f. Gewässerkunde; 1999

33. Reise K, Gollasch S, Wolff WJ. Introduced marine species of the North Sea coast. Helgol Meeresunters. 1999;52:219-43.

34. Vandepitte L, Decock W, Mees J (2010) Belgian register of marine species, compiled and validated by the VLIZ Belgian Marine Species Consortium. VLIZ Special Publication 46. Vlaams Instituut voor de Zee (VLIZ), Oostende.

35. Guilloux L, Rigaut-Jalabert F, Jouenne F, Ristori S, Viprey M, Not F, Vaulot D, Simon N. An annotated checklist of marine phytoplankton taxa at the SOMLIT-Astan time series off Roscoff (Western English Channel, France): data collected from 2000 to 2010. Cah Biol Mar. 2013;54:247-56.

36. Costello MJ, Bouchet P, Boxshall G, Arvantidis C, Appeltans W. European register of marine species. 2008. http://www.marbef.org/data/erms.php. Consulted on 2018-03-21.

37. Armonies W, Reise K. Faunal diversity across a sandy shore. Mar Ecol Prog Ser. 2000;196:49-57.

38. Fonseca VG, Carvalho GR, Sung W, Johnson HF, Power DM, Neill SP, Üacker M, Blaxter ML, Lambshead PJD, Thomas WK, Creer S. Second-generation environmental sequencing unmasks marine metazoan biodiversity. Nat Commun. 2010;1:98. https://doi.org/10.1038/ncomms1095.

39. Sinniger F, Pawlowski J, Harii S, Gooday AJ, Yamamoto H, Chevaldonné $\mathrm{P}$, Cedhagen T, Carvalho G, Creer S. Worldwide analysis of sedimentary DNA reveals major gaps in taxonomic knowledge of deep-sea benthos. Front Mar Sci. 2016;3:92. https://doi.org/10.3389/fmars.2016.00092.

40. Rick JJ, Wiltshire KH. Veränderungen des Phytoplanktons in der Nordsee. In: Loźan JL, Breckle S-W, Müller R, Rachor E, editors. Warnsignal Klima: Die Biodiversität. Hamburg: Wissenschaftliche Auswertung; 2016.

41. Baird D, Asmus H, Asmus R. Effect of invasive species on the structure and function of the Sylt-Rømø Bight ecosystem, northern Wadden Sea, over three time periods. Mar Ecol Prog Ser. 2012;462:143-62.

42. Dekker R, Beukema JJ. Long-term dynamics and productivity of a successful invader: the first three decades of the bivalve Ensis directus in the western Wadden Sea. J Sea Res. 2012;71:31-40.

43. Buschbaum C, Cornelius A, Goedknegt MA. Deeply hidden inside introduced biogenic structures_-Pacific oyster reefs reduce detrimental barnacle overgrowth on native blue mussels. J Sea Res. 2016;117:20-6.

44. Reise K, Buschbaum C, Büttger H, Wegner KM. Invading oysters and native mussels: from hostile takeover to compatible bedfellows. Ecosphere. 2017. https://doi.org/10.1002/ecs2.1949.

45. Polte P, Buschbaum C. Native pipefish (Entelurus aequoreus) promoted by the introduced seaweed Sargassum muticum in the northern Wadden Sea, North Sea. Aqua Biol. 2008;3:11-8.

46. Hale SS, Hughes MM, Buffum HW. Historical trends of benthic invertebrate biodiversity spanning 182 years in a southern New England estuary. Estuaries Coasts. 2018. https://doi.org/10.1007/s12237-018-0378-7.

\section{Data sets}

47. Rick JJ, Drebes G, Elbrächter M, Wiltshire KH. Semi-quantitive microplankton analysis (Sylt Roads Time Series) in the Wadden Sea off List, Sylt, North Sea in 1987; 2016. https://doi.org/10.1594/pangaea.861296.

48. Rick JJ, van Beusekom J, Asmus R, Wiltshire KH. Long-term quantitative microplankton analysis at Sylt Roads LTER (1992-2013), Wadden Sea, North Sea, links to data sets; 2017. https://doi.org/10.1594/panga ea.150033.

49. Martens P. Abundance of zooplankton at times series station List Reede in 1975; 2007. https://doi.org/10.1594/pangaea.646247.

50. Martens P. Abundance of zooplankton at times series station List Reede in 2011; 2012. https://doi.org/10.1594/pangaea.774882. 
51. Armonies W. Plathelminthes in surface sediments off Sylt; 2017. https:// doi.org/10.1594/pangaea.869108.

52. Armonies W, Reise K. Macrofauna and surface sediments in Sylt-Rømø Bight in the Northern Wadden Sea (North Sea); 2003. https://doi. org/10.1594/pangaea.873243.

53. Armonies W, Buschbaum C. Environmental compatibility of sand replenishment in the surf zone off the Island of Sylt, 2009-2010; 2010. https:// doi.org/10.1594/pangaea.874933.
54. Armonies W, Buschbaum C, Hellwig-Armonies M. Species composition and abundance of macrozoobenthos in the SE North Sea; 2013. https:// doi.org/10.1594/pangaea.870467.

55. Armonies W, Asmus H, Buschbaum C. Macrozoobenthos and sediments in the prospective wind farm "Butendiek" (North Sea) between August 2001 and August 2003; 2017. https://doi.org/10.1594/pangaea.873727.
Ready to submit your research? Choose BMC and benefit from:

- fast, convenient online submission

- thorough peer review by experienced researchers in your field

- rapid publication on acceptance

- support for research data, including large and complex data types

- gold Open Access which fosters wider collaboration and increased citations

- maximum visibility for your research: over $100 \mathrm{M}$ website views per year

At BMC, research is always in progress.

Learn more biomedcentral.com/submissions 